\title{
Modelling mode choice for freight transport using advanced choice experiments
}

\author{
Ana Isabel Arencibia Pérez \\ Institute of Tourism and Sustainable Economic Development. University of Las Palmas de Gran Canaria, \\ Spain \\ aarencibia@acciones.ulpgc.es \\ María Feo Valero \\ Instituto de Economía Internacional. University Jaume I de Castellón, Spain \\ maria.feo@eco.uji.es \\ Leandro García Menéndez \\ Instituto de Economía Internacional. University of Valencia, Spain \\ leandro.garcia@uv.es

\section{Concepción Román García} \\ Institute of Tourism and Sustainable Economic Development. University of Las Palmas GC. \\ Facultad de Economía Empresa y Turismo, módulo D, Campus de Tafira, 35017 Las Palmas G.C., Spain \\ +34928451796 \\ croman@daea.ulpgc.es
}

- Corresponding author 


\begin{abstract}
:
In this paper we use advanced choice modelling techniques to analyze demand for freight transport in a context of modal choice. To this end, a stated preference (SP) survey was conducted in order to estimate freight shipper preferences for the main attributes that define the service offered by the different transport modes. From a methodological point of view, we focus on two critical issues in the construction of efficient choice experiments. Firstly, in obtaining good quality prior information about the parameters; and secondly, in the improved quality of the experimental data by tailoring a specific efficient design for every respondent in the sample.

With these data, different mixed logit models incorporating panel correlation effects and accounting for systematic and random taste heterogeneity are estimated. For the best model specification we obtain the willingness to pay for improving the level of service and the elasticity of the choice probabilities for the different attributes. Our model provide interesting results that can be used to analyze the potential diversion of traffic from road (the current option) to alternative modes, rail or maritime, as well as to help in the obtaining of the modal distribution of commercial traffic between Spain and the European Union, currently passing through the Pyrenees.
\end{abstract}

KEYWORDS: Freight Transport, Discrete Choice Experiments, Stated Preference, Willingness to Pay, Discrete Choice Models.

\title{
Highlights
}

- We use discrete choice experiments to analyze demand for freight transport in a context of modal choice.

- We tailor a specific efficient design for every respondent in the sample using parameters' priors obtained from a previous orthogonal design.

- We study freight shipper preferences for the main attributes that define the service offered by the different transport modes.

- We estimate mixed logit models incorporating panel correlation effects and accounting for systematic and random taste heterogeneity.

- We obtain willingness to pay figures for improving the level of service and the elasticity of the choice probabilities for the different attributes. 


\section{INTRODUCTION}

Even though the current economic crisis is taking some pressure off the saturation of roads, thus relieving traffic in the two main Pyrenean corridors that connect Spain with Europe, it is still of vital importance in the Spanish transport agenda. The very sensitive natural environment through which the traffic flows and the high economic cost of expanding road capacities in mountainous areas make it even more necessary to shift a significant amount of cargo from road to rail and maritime intermodal alternatives. Thus, rebalancing the modal pattern and improving the efficiency of the transport system is paramount in determining the appropriate basis for the Spanish economic growth.

Road pricing schemes and subsidies to intermodal alternatives, such as the Ecobonus, without a doubt increase the competitiveness of rail and maritime logistics chains. However, the fact that the modal shift objectives set out in the 2001 Transport White Paper (European Commission, 2001) have still not been accomplished indicates the importance given to qualitative aspects of the transport service and the need to further increase the efficiency and quality of intermodal alternatives.

Given the historical trend of the modal distribution for freight transport over the past decades in Spain (characterised by the prevalence of road transport), the compatibility of higher economic growth with sustainable development of the transport system will demand considerable investment by the authorities. However, the urgent need to reconcile investment spending and budgetary stability requires national policy makers to carry out a rigorous assessment of transport projects in order to attain efficient resource allocation. The ability to make investment decisions however will depend on the degree of knowledge of the transport demand as well as on the accuracy with which benefits and costs associated to different actions are quantified.

Thus, an increasing number of agencies incorporate cost-benefit analysis (CBA) in the evaluation of transport projects. Unlike financial analysis, which only takes into account current income and costs incurred by the operator throughout the project, in CBA net social benefits are obtained by comparing benefits and socioeconomic costs of all stakeholders involved in the project. These benefits and costs include both, elements easily quantifiable in monetary terms and elements, such as the value of time, for which there is no direct measurement therefore, making their economic assessment more difficult.

Savings in travel time represents one of the most important benefits derived from infrastructure investments in the case of freight and passenger transport. Despite being the main benefit for the majority of transport projects, researchers have not been able to reach a consensus neither in the magnitude nor in the nature of the value-of-time figures used in project evaluation. The absence of consensus is even higher with regard to freight transport. Indeed, the difficulties associated with obtaining information in this area limit 
the scope of empirical applications and thereby the methodological debate around the valuation of freight transit time.

As pointed out by Ben-Akiva et al. (2008), the modelling for freight transport demand has evolved significantly over the past decades, from the use of aggregate models based on global data of shippers and shipments, to the use of more sophisticated disaggregated models based on individual data. In this regard, Tavasszy and de Jong (2014), Ben-Akiva et al. (2013), Nuzzolo et al. (2013a) and Chow et al. (2010) provide interesting reviews of the state-of-the-art literature regarding freight transport modelling. In contrast with passenger transport, the use of behavioural models to analyse freight transport demand has been much more limited because of the difficulties associated with data collection. FeoValero et al. (2011) identify the most critical issues in freight transport demand modelling; highlighting the identification of the decision-maker, the heterogeneity of the transport flows and the definition of the explanatory variables. Despite these difficulties, the use of freight disaggregate models is increasingly widespread. In this sense, we can cite the work of Bergantino et al. (2013), Masiero and Hensher (2012), Arunotayanun and Polak (2011), Feo et al. (2011), Rich et al. (2009), Polak and Arunotayanun (2009), Bergantino and Bolis (2008), Beuthe and Bouffioux (2008), Brook and Trifts (2008), de Jong and Ben-Akiva (2007), Daniellis and Marcucci (2005), Marcucci and Scaccia (2004), Shinghal and Fowkes (2002), Kurri et al. (2000), Nuzzolo and Russo (1997), and Modenese-Vieira (1992) among the more recent contributions, many of them using stated preference (SP) techniques.

According to the sequential four-step model, transport demand consists in the analysis of four different stages: trip production, trip distribution, modal split and traffic assignment (Ortúzar and Willumsen, 2011). As recognised by de Jong et al. (2012), this structure has been adopted in freight transport modelling with some success, though additional steps are sometimes required in order to transform trade flows, normally expressed in monetary units, into transport vehicle flows. This paper aims to contribute to the field of freight transport demand analysis by estimating a discrete choice model that can be used to analyse the potential diversion of traffic from road to alternative modes, rail or maritime, as well as to help in the obtaining of the modal distribution of commercial traffic between Spain and the European Union, currently passing through the Pyrenees. In particular, the analysis is focused on modelling the third stage of the conventional four-step disaggregate model: the mode choice. This stage is one of most relevant as modal distribution results are among the main factors explaining freight transport externalities (de Jong, 2014a). To this end, a SP survey, based firstly on an orthogonal design and secondly, on an efficient discrete choice experiment, was conducted in order to analyse the freight shipper preferences for the attributes that define the service offered by the different transport modes. From a methodological point of view, we focus on two critical issues in the construction of efficient designs. The first is on obtaining good quality information about the parameters; and, the second, on the improved quality of the experimental data by tailoring a specific efficient design for every respondent in the sample. Extended 
information on the difficulties linked to the use of tailored efficient designs in the area of freight transport and how the proposed two-step fieldwork copes with them can be found in Feo et al. (2014), where the analysis is focused on the context of modal choice between road and rail in a domestic corridor in Spain. Whereas the advantages of using efficient designs have been widely acknowledged by many authors, not many applications have been focussed on trying to address these two problems together. In fact, this research, together with the work of Feo et al. (2014), is to our knowledge, the only contribution using individual-specific efficient designs in the field of freight transport. Furthermore, the present study is the only one that analyses modal competition at an international level.

\section{DATA COLLECTION AND EXPERIMENTAL DESIGN}

The population studied in this application are the producers / distributors of manufactured goods, that in 2010 handled unitised shipments in the corridor linking Madrid with the Netherlands / Belgium / Northern France / West Germany (see Figure 1). This corridor accounted for $4.3 \%$ of traffic channelled between Spain and continental Europe in the reference period. It is also important to point out that there is effective competition among the transport modes under analysis in this corridor: road, rail and maritime.

Whilst in previous research the analysis was circumscribed to freight forwarders (Feo et al., 2011), in this application the population being studied is confined to the company responsible for sending the shipment (shipper or receiver), in order to increase the population size and the response rate. To ensure that the company selected corresponded to the real decision-maker, certain filter questions were included in the questionnaire before starting the interview.

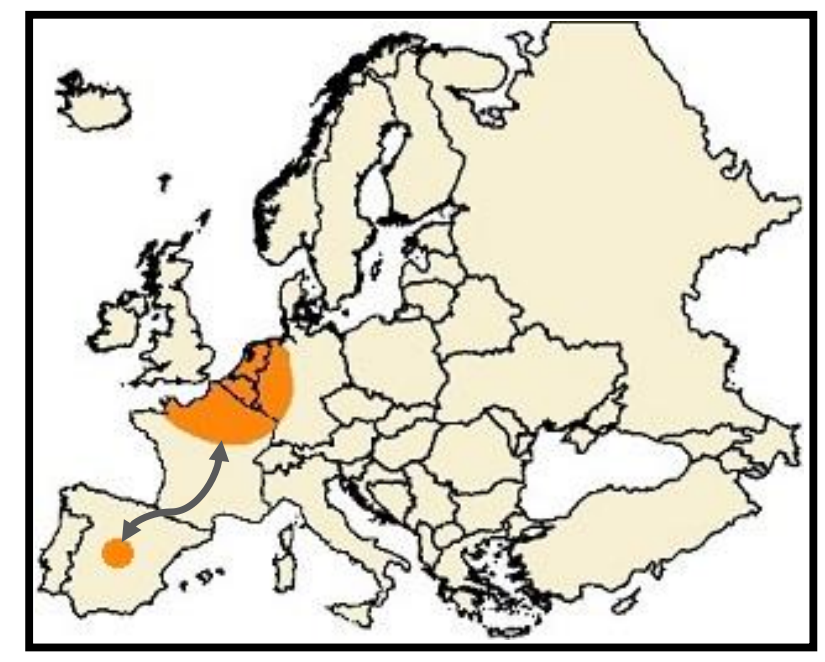

Figure 1. Corridor analysed

A personal interview was arranged with the person responsible for managing the transport shipments in the corridor under study. The average length of the interviews was about 20 minutes in which, using a laptop, the interviewee was guided along the questionnaire 
designed in Sawtooth Software release 6.6. The use of computer support and specialised software not only helped us to minimise errors in data collection, but also allowed us to customise the interview to the context of each respondent. The surveys were conducted during October and November 2011 by a group of properly trained interviewers whose qualifications and knowledge on the project contributed to increasing the quality of the information obtained.

The total sample consisted of 93 companies located in the Autonomous Region of Madrid. Each firm provided information about the representative shipment in the corridor allowing us to obtain a total of 1674 statistical SP observations (18 per shipment). Companies were randomly selected from the directory of Spanish Exporting and Importing Companies developed by the Spanish High Council of Chambers of Commerce (http://aduanas.camaras.org). Our sample represented 4.4\% of total Madrilenian companies identified in the directory as exporting or importing to the countries under study in 2010. As the analysed transport corridor is restricted to Northern France and West Germany and to non-refrigerated-unitised shipments, it is reasonable to expect a higher percentage.

In a second wave of surveys conducted during the first semester of 2012, we used information obtained previously to improve the choice experiment, tailoring an efficient design for each respondent who participated in the first phase of the study.

The questionnaire was divided into four main sections: i) the first section was designed to obtain general information about the characteristics of the company and its logistic dimension; ii) the second was devoted to collecting information on the main characteristics of the reference shipment (cost, transit time, delays, etc.) as well as on the minimum level of service required for each of the attributes; iii) the third section provided information on the importance of the main attributes that define the transport service, as well as the level of quality perceived; iv) finally, the fourth section was devoted to collecting the decisionmaker preferences in an SP game.

Table 1 shows the composition of the sample by type of company (producer or distributor) and size (micro, small, medium and large), and the modal distribution of shipments identified during the fieldwork. Transport alternatives used at the time of the fieldwork were pure road transport and intermodal alternatives using rail, maritime or air as the main mode of transport and road for the origin and destination haulage.

As can be seen most of the companies are small and medium size firms. Our sample is therefore consistent with the Spanish production structure. Information regarding the proportion of companies having a specific logistic department is also displayed. The results obtained show, as might be expected, a positive correlation between the size of the company and its involvement in logistics management. Bigger companies with specific logistics departments should be in a better position to optimise transport chains and should be therefore more willing to use alternative modes. On the contrary, small companies that do not have such supporting structures for logistics are more likely to be inclined to continue using their current transport option. The results obtained partially confirm this 
hypothesis as, while road is the dominant mode in all cases, the share of intermodal modes increases slightly as company size increases.

Concerning the distinction between producers and distributors, our initial hypothesis was that the latter would pay more attention to logistics issues than the former -as their core activity was precisely distributing goods- and they would therefore display more diverse modal splits. However in our sample the road transport quota is roughly the same for both types of companies.

Figure 2 shows the level of importance of the following factors in the choice of transport provider for the reference shipment: transport cost, transit time, frequency, punctuality, absence of losses and damages, flexibility ${ }^{1}$, track and trace, environmental impact and schedules $^{2}$. This graph provides quick and visual information on the distribution of the assessments made by the companies included in the sample considering a five-point Likert scale, where 1 means "very low" and 5 means "very high" importance. Figures in brackets under the attribute name represent the average score obtained by the attribute from a maximum of 5 points. According to these results, the most important criterion is the reliability in delivery times, that is, punctuality; the transport cost and the transit time, with an average score of above 4 points. In contrast, the less valued attribute is the environmental impact of the transport chain with an average score close to 3 points.

\begin{tabular}{|c|c|c|c|c|c|c|}
\hline Type of firm (Size) & $\begin{array}{c}\mathbf{N}^{\circ} \text { of } \\
\text { companies } \\
\text { (\%/Total) }\end{array}$ & $\begin{array}{c}\mathrm{N}^{\mathbf{o}} \text { of } \\
\text { companies } \\
\text { with a } \\
\text { logistics } \\
\text { department }\end{array}$ & $\underset{(\%)}{\text { Road }}$ & $\begin{array}{l}\text { Intermodal- } \\
\text { Maritime } \\
\text { (road-sea- } \\
\text { road) } \\
(\%)\end{array}$ & $\begin{array}{l}\text { Intermodal- } \\
\text { Rail } \\
\text { (road-rail- } \\
\text { road) } \\
(\%)\end{array}$ & $\begin{array}{l}\text { Intermodal- } \\
\text { Air } \\
\text { (road-air- } \\
\text { road) } \\
(\%)\end{array}$ \\
\hline $\begin{array}{l}\text { Micro firm } \quad(<10 \\
\text { workers })\end{array}$ & $\begin{array}{c}17 \\
(18 \%)\end{array}$ & $\begin{array}{c}3 \\
(18 \%)\end{array}$ & 95 & 1 & 0 & 4 \\
\hline $\begin{array}{l}\text { Small (between } 10 \\
\text { and } 49 \text { workers) }\end{array}$ & $\begin{array}{c}38 \\
(41 \%)\end{array}$ & $\begin{array}{c}18 \\
(47 \%)\end{array}$ & 92 & 2 & 0 & 6 \\
\hline $\begin{array}{l}\text { Medium (between } \\
50 \text { and } 250 \text { workers) }\end{array}$ & $\begin{array}{c}31 \\
(33 \%)\end{array}$ & $\begin{array}{c}22 \\
(71 \%)\end{array}$ & 87 & 2 & 1 & 10 \\
\hline $\begin{array}{lll}\text { Large } & (> & 250 \\
\text { workers }) & & \end{array}$ & $\begin{array}{c}7 \\
(8 \%)\end{array}$ & $\begin{array}{c}7 \\
(100 \%)\end{array}$ & 86 & 8 & 3 & 3 \\
\hline Total & 93 & 93 & 89 & 3 & 1 & 7 \\
\hline Producer & $\begin{array}{c}69 \\
(74 \%)\end{array}$ & $\begin{array}{c}41 \\
(59 \%)\end{array}$ & 89 & 4 & 1 & 6 \\
\hline Distributor & $\begin{array}{c}34 \\
(26 \%)\end{array}$ & $\begin{array}{c}15 \\
(44 \%)\end{array}$ & 90 & 1 & 0 & 9 \\
\hline Total & 93 & 93 & 89 & 3 & 1 & 7 \\
\hline
\end{tabular}

Table 1. Modal distribution of the shipments to Europe in the sample. 


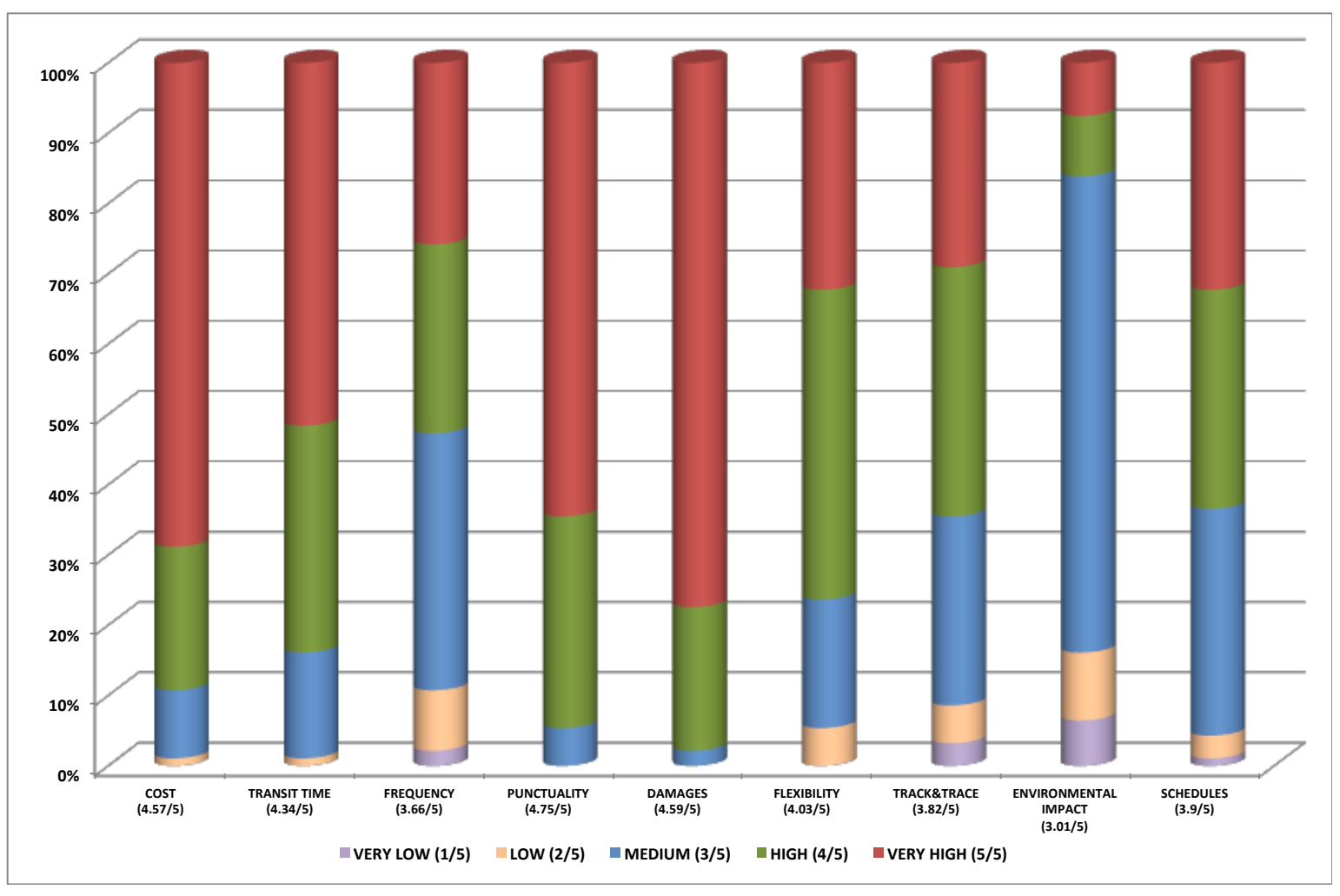

Figure 2. Importance of factors in the choice of transport provider for the reference shipment.

\subsection{The discrete choice experiment}

The fieldwork regarding the stated choice (SC) experiment was structured into two separate phases. Firstly, we collected information on the main characteristics of the shipment as well as the decision-maker preferences with respect to the modal choice, considering an orthogonal SC experiment. Thus, we were able to estimate preliminary models in order to obtain the parameter priors required in the construction of the Defficient experiment conducted during the second phase of the fieldwork.

\section{The orthogonal design}

The main feature of orthogonal designs is that attributes are treated as statistically independent variables, so that it is possible to estimate the influence of each factor upon the observed outcomes. In other words, the design matrix is made up a set of perpendicular vector columns. In a first phase, and in order to obtain preliminary information about the preferences between the current mode of transport and the hypothetical intermodal alternative options, an orthogonal SP design was created considering the more relevant set of attributes, based on the specific interests of the study as well as on previous research and information available regarding the determinants of modal choice in freight transport (Cullinane and Toy, 2000; Feo et al., 2011). Attributes and levels considered in the experiment are presented in Table 2. Transport cost is measured in euros and defined as the cost per shipment of the door-to-door service; transit time represents the duration, in days, 
of the door-to-door service; punctuality is expressed as the percentage of shipments that meet the deadlines originally planned; and finally, the service frequency is expressed in terms of the number of departures per week.

\begin{tabular}{|c|c|c|c|c|}
\hline \multicolumn{2}{|c|}{ Attributes - levels } & $\begin{array}{c}\text { Current } \\
\text { alternative }\end{array}$ & $\begin{array}{c}\text { Intermodal alternative } \\
\text { Game 1 }\end{array}$ & $\begin{array}{c}\text { Intermodal alternative } \\
\text { Game 2 }\end{array}$ \\
\hline Cost & 1 & & $-25 \%$ & $+20 \%$ \\
(Euros per & 2 & Current level & $-15 \%$ & $+10 \%$ \\
shipment) & 3 & & $-10 \%$ & $+5 \%$ \\
\hline Transit Time & 1 & & +1 day & -1 day \\
(Days) & 3 & Current level & +2 days & $-1 / 2$ day \\
& 1 & & +3 days & Current level \\
\hline Punctuality & 2 & Current level & -5 percentage points & +5 percentage points \\
$(\%)$ & 3 & & -10 percentage points & +7 percentage points \\
\hline Service frequency & 1 & & 1 weekly departures & 2 weekly departures \\
$\left(N^{o}\right.$ of weekly & 2 & Current level & 2 weekly departures & 3 weekly departures \\
departures) & 3 & & 3 weekly departures & 5 weekly departures (Mon-Fri) \\
\hline
\end{tabular}

Table 2. Attributes and levels. Orthogonal design

One of the main reasons why SP experiments have become so popular is because of their ability to mimic the decisions that individuals make in real markets that are otherwise difficult to observe. Thus, during the interview, we requested the individual to participate in two SC games, consisting in nine hypothetical choice situations each. The first game involves the choice between the current option, defined in terms of previous information collected during the first part of the interview, and a hypothetical intermodal alternative that is cheaper but with lower or equal level-of-service in the rest of the attributes, so that there is a real trade-off to the decision-maker. What is intended with this first game is to obtain information in order to analyse preferences for other transportation methods that involve lower costs, but offer a poorer service. The second game, however, considers the choice between the current alternative and an intermodal alternative that involves a higher cost but offers better conditions for the other attributes considered. In this case, the aim is to analyse preferences for an alternative transportation mode that is more expensive but offers better service than that currently provided for the shipment of reference.

It is worth pointing out that although the alternatives were unlabelled in both cases, implicitly the first game posed the choice between pure road and intermodal-rail (road-railroad); and the second, the choice between pure road and a motorway of the sea service (road-maritime-road). ${ }^{3}$

Given the number of attributes and levels, the full factorial design would involve the evaluation of $3^{4}=81$ choices. In order to reduce the number of options, an orthogonal fractional factorial design ${ }^{4}$ consisting in 9 choice situations was created with the aid of the 
catalogues provided by Kocur et al. (1982). This design allows for the independent estimation of the main effects under the assumption that all interactions are negligible. Despite the fact that the use of orthogonal designs has been the mainstream in many transportation studies, authors are aware that these designs are created to satisfy the econometric properties of linear regression models, not discrete choice models like the Multinomial Logit (see Rose and Bliemer, 2009 for an excellent discussion on the performance of efficient designs in comparison with other methods). In this particular case, we only use the orthogonal design to obtain parameter priors for the efficient design created for the second phase of the study. Given the lack of previous information in this market, we believe that this knowledge of the parameters would provide more assistance than that borrowed from other studies undertaken in different contexts. Table 3 presents the hypothetical choice situations considered in the orthogonal designs used during the first phase of the fieldwork.

\begin{tabular}{|c|c|c|c|c|c|c|c|c|}
\hline \multirow{2}{*}{$\begin{array}{l}\text { Choice } \\
\text { situation }\end{array}$} & \multicolumn{4}{|c|}{ Game 1} & \multicolumn{4}{|c|}{ Game 2} \\
\hline & Cost & $\begin{array}{c}\text { Transit } \\
\text { Time }\end{array}$ & Punctuality & Frequency & Cost & $\begin{array}{c}\text { Transit } \\
\text { Time }\end{array}$ & Punctuality & Frequency \\
\hline 1 & $-25 \%$ & +1 day & $\begin{array}{l}-2 \text { perc. } \\
\text { points }\end{array}$ & $1 \mathrm{~d} /$ week & $+20 \%$ & -1 day & current & $2 \mathrm{~d} /$ week \\
\hline 2 & $-25 \%$ & +2 days & $\begin{array}{l}-5 \text { perc. } \\
\text { points }\end{array}$ & $3 \mathrm{~d} /$ week & $+20 \%$ & $-1 / 2$ day & $\begin{array}{l}+5 \text { perc. } \\
\text { points }\end{array}$ & $5 \mathrm{~d} /$ week \\
\hline 3 & $-25 \%$ & +3 days & $\begin{array}{l}-10 \text { perc. } \\
\text { points }\end{array}$ & $2 \mathrm{~d} /$ week & $+20 \%$ & current & $\begin{array}{l}+7 \text { perc. } \\
\text { points }\end{array}$ & $3 \mathrm{~d} /$ week \\
\hline 4 & $-15 \%$ & +1 day & $\begin{array}{l}-5 \text { perc. } \\
\text { points }\end{array}$ & $2 \mathrm{~d} /$ week & $+10 \%$ & -1 day & $\begin{array}{l}+5 \text { perc. } \\
\text { points }\end{array}$ & $3 \mathrm{~d} /$ week \\
\hline 5 & $-15 \%$ & +2 days & $\begin{array}{l}-10 \text { perc. } \\
\text { points }\end{array}$ & $1 \mathrm{~d} /$ week & $+10 \%$ & $-1 / 2$ day & $\begin{array}{l}+7 \text { perc. } \\
\text { points }\end{array}$ & $2 \mathrm{~d} /$ week \\
\hline 6 & $-15 \%$ & +3 days & $\begin{array}{l}-2 \text { perc. } \\
\text { points }\end{array}$ & $3 \mathrm{~d} /$ week & $+10 \%$ & current & current & $5 \mathrm{~d} /$ week \\
\hline 7 & $-10 \%$ & +1 day & $\begin{array}{l}-10 \text { perc. } \\
\text { points }\end{array}$ & $3 \mathrm{~d} /$ week & $+5 \%$ & -1 day & $\begin{array}{l}+7 \text { perc. } \\
\text { points }\end{array}$ & $5 \mathrm{~d} /$ week \\
\hline 8 & $-10 \%$ & +2 days & $\begin{array}{l}-2 \text { perc. } \\
\text { points }\end{array}$ & $2 \mathrm{~d} /$ week & $+5 \%$ & $-1 / 2$ day & current & $3 \mathrm{~d} /$ week \\
\hline 9 & $-10 \%$ & +3 days & $\begin{array}{l}-5 \text { perc. } \\
\text { points }\end{array}$ & $1 \mathrm{~d} /$ week & $+5 \%$ & current & $\begin{array}{l}+5 \text { perc. } \\
\text { points }\end{array}$ & $2 \mathrm{~d} /$ week \\
\hline
\end{tabular}

Table 3. Choice situations. Orthogonal design

\section{Preliminary results}

To obtain preliminary estimates with orthogonal data we considered a behavioural model (Winston, 1983) whose specification is based on random utility maximisation (McFadden, 1974; Domencich and McFadden, 1975 and Manski, 1977). Under the assumption of linear utility, maximum likelihood estimates for the unknown set of parameters were obtained with the software Biogeme release 2.0 (Bierlaire, 2003 and 2008). Estimation results for a multinomial Logit ${ }^{5}$ specification are presented in Table 4. 
For model MNL1 (equation (1)), transport cost (C), transit time (T) and frequency (F), presented the expected sign and were significant at the $95 \%$ confidence level. However a counterintuitive result was obtained for the punctuality $(\mathrm{P})$ coefficient, as it was estimated with the wrong sign, although it was not significant at a reasonable confidence level. This result was not consistent with the existing evidence about the perception of this variable, or with the importance given to it.

$$
\begin{aligned}
& U_{\text {road }, n}=\theta_{c} C_{\text {road }, n}+\theta_{t} T_{\text {road }, n}+\theta_{p} P_{\text {road }, n}+\theta_{f} F_{\text {road }, n}+\varepsilon_{\text {road }, n} \\
& U_{\text {intermodal }, n}=\theta_{c} C_{\text {intermodal }, n}+\theta_{t} T_{\text {intermodal }, n}+\theta_{p} P_{\text {intermodal }, n}+\theta_{f} F_{\text {intermodal }, n}+\varepsilon_{\text {intermodal }, n}
\end{aligned}
$$

A possible explanation to this result may be due to the inherent complexity of the definition of reliability in delivery times (punctuality). Indeed, it may be recalled that this concept incorporates both the percentage of shipments that are affected by significant delays on the delivery date originally scheduled -that is, shipments arriving once the shipper/receiver time window is closed- and the absolute magnitude of such delays ${ }^{6}$. Therefore, we believe that the wrong sign obtained for this variable could be due to a misinterpretation of the meaning of punctuality, where those interviewed understood this variable to mean the existence of significant delays.

In order to obtain a sensible figure for the coefficient of this attribute we used previous information collected in the survey to build a proxy of the average magnitude of the delay (D), in terms of the information provided about the punctuality (\% of shipments delivered on time) and significant delays' threshold of the shipment of reference (moment from which the interviewee considers the delay becomes relevant). Thus, the attribute "percentage of punctual shipments" was replaced by "magnitude of delays". That is, we are assuming in all cases that the reference shipment is significantly delayed, the difference being in the level of service offered by one or other alternative in the magnitude of such delay (expressed as "days of delay in relation to the initially planned delivery time"). With this new variable, we proceeded to re-estimate the model specified in equation (2) and estimation results correspond to MNL2 in Table 4.

$$
\begin{aligned}
& U_{\text {road }, n}=\theta_{c} C_{\text {road }, n}+\theta_{t} T_{\text {road }, n}+\theta_{d} D_{\text {road }, n}+\theta_{f} F_{\text {road }, n}+\varepsilon_{\text {road }, n} \\
& U_{\text {intermodal }, n}=\theta_{c} C_{\text {intermodal }, n}+\theta_{t} T_{\text {intermodal }, n}+\theta_{d} D_{\text {intermodal }, n}+\theta_{f} F_{\text {intermodal }, n}+\varepsilon_{\text {intermodal }, n}
\end{aligned}
$$

As can be seen, when we define the reliability in terms of the relative magnitude of the delays all variables are significant and are estimated with the correct sign. This result suggests that in the corridor under analysis decision-makers have internalised high levels of service in terms of the percentage of delayed shipments, where the magnitude of the delay is what makes the difference between alternatives. Therefore, we decided to rethink the construction of the efficient design taking into account the definition of the reliability in terms of the magnitude of the delay rather than in terms of the percentage of shipments that were suffering delays. The results of this model will provide parameters' prior information required for the generation of the efficient design linked to the second phase of the fieldwork. 


\section{Efficient design}

One of the most popular methods to construct efficient designs is based on the minimisation of the D-error, which is defined in terms of the asymptotic variancecovariance (VC) matrix, which depends, in turn, on the second derivatives of the loglikelihood function. Recently, many authors have highlighted the advantages of using efficient designs when dealing with SC data. Among the most important, we can cite the ability of efficient designs to obtain more reliable estimates with a smaller sample size (Bliemer and Rose, 2005). Moreover, the difficulty entailed in the computation of the Derror varies with the complexity of the choice model to be estimated. Therefore, even in the case of the simplest multinomial Logit model, the value of the D-error varies with the design matrix and the value of the unknown parameters.

\begin{tabular}{|c|c|c|c|}
\hline \multicolumn{2}{|l|}{ Attributes } & \multicolumn{2}{|c|}{$\begin{array}{c}\text { Estimate } \\
\text { (t-test) }\end{array}$} \\
\hline & & MNL1 & MNL2 \\
\hline $\begin{array}{c}\text { Door-to-door Transport Cost (C) } \\
\text { Euros per shipment }\end{array}$ & $\theta_{c}$ & $\begin{array}{c}-0.00357 \\
(-8.51)\end{array}$ & $\begin{array}{c}-0.00347 \\
(-8.33)\end{array}$ \\
\hline $\begin{array}{c}\text { Door-to-door Transit time (T) } \\
\text { Days }\end{array}$ & $\theta_{t}$ & $\begin{array}{l}-0.458 \\
(-8.06)\end{array}$ & $\begin{array}{l}-0.357 \\
(-7.68)\end{array}$ \\
\hline $\begin{array}{c}\text { Punctuality (P) } \\
\text { \% of shipments arriving on time }\end{array}$ & $\theta_{p}$ & $\begin{array}{l}-0.0156 \\
(-1.00)\end{array}$ & \\
\hline $\begin{array}{c}\text { Delay (D) } \\
\text { Magnitude of the delay, in days }\end{array}$ & $\theta_{d}$ & $\begin{array}{l}- \\
-\end{array}$ & $\begin{array}{l}-0.107 \\
(-4.73)\end{array}$ \\
\hline $\begin{array}{c}\text { Frequency }(\mathrm{F}) \\
\mathrm{N}^{\mathrm{o}} \text { of weekly departures }\end{array}$ & $\theta_{f}$ & $\begin{array}{l}0.278 \\
(9.91)\end{array}$ & $\begin{array}{l}0.255 \\
(9.03)\end{array}$ \\
\hline$\rho^{2}$ & & 0.131 & 0.141 \\
\hline Adjusted $\rho^{2}$ & & 0.128 & 0.137 \\
\hline$l *(\mathbf{0})$ & & -1160 & -1160 \\
\hline$l^{*}(\theta)$ & & -1007 & -997 \\
\hline Observations & & 1674 & 1674 \\
\hline
\end{tabular}

Table 4. Estimation results. Orthogonal design data.

To cope with these two critical issues in the construction of our experimental dataset in the present paper: i) we use good quality prior information about unknown parameters by using estimates derived from the previous orthogonal design; and ii) we try to achieve the highest possible efficiency by generating a specific efficient design for every respondent, using previous information about the current option to define attribute levels and parameter priors obtained in the above section.

In this regard and in order to gain realism in the outcomes of the experiment, we customise the levels of the attributes to the respondent's current experience. Thus, alternatives presented in the choice sets are different for each respondent and are defined by pivoting 
attribute level values around the reference alternative. As the efficiency of the design depends on the attribute values, in an ideal situation a specific design should be created for every single respondent. In this paper we follow the recommendation of Rose et al. (2008) by collecting data in two different phases and optimising the design for each individual based on their reference levels. Although the generation of a specific design to each individual could confound individual heterogeneity with design heterogeneity, to the best of our knowledge this problem does not have a satisfactory solution in cases where customising the design to gain realism in the choice task is paramount ${ }^{7}$.

Attributes and levels corresponding to the two games are presented in Tables 5 and 6 . On this occasion, as we already had accurate information on the levels of service displayed by the reference alternative, the levels of frequency and delays were re-adjusted to the current level of service in order to further increase the realism of the experiment.

N-gene software (ChoiceMetrics, 2009) was used to build the efficient design for every individual in the sample considering a multinomial Logit specification.

A web questionnaire including only the new choice games was administered to all firms that participated in the first phase of the study. Previous contact by telephone with the appropriate person helped us to improve the response rate. At the end of this second wave of interviews we obtained a total of 972 observations corresponding to 54 companies, which represent $58 \%$ of the initial sample. Our final sample might therefore not be as large as otherwise desired, but this makes our two-step fieldwork and the use of efficient designs all the more relevant, as they allow us to obtain more reliable estimates with smaller sample sizes.

\begin{tabular}{|c|c|c|c|}
\hline \multicolumn{2}{|c|}{ Attributes - levels } & Current alternative & $\begin{array}{c}\text { Intermodal alternative } \\
\text { game } 1\end{array}$ \\
\hline Door-to-door transport & 1 & \multirow{3}{*}{ Current level } & $-25 \%$ \\
\hline cost & 2 & & $-15 \%$ \\
\hline (Euros per shipment) & 3 & & $-10 \%$ \\
\hline Door-to-door transit & 1 & \multirow{3}{*}{ Current level } & +1 day \\
\hline time & 2 & & +2 days \\
\hline (Days) & 3 & & +3 days \\
\hline Delay & 1 & \multirow{3}{*}{$\begin{array}{l}-0.5 \text { day } \\
\text { Current level } \\
+0.5 \text { day }\end{array}$} & +0.5 day \\
\hline (Days) & 2 & & +1 day \\
\hline Current level $\leq 1$ day & 3 & & +1.5 days \\
\hline Delay & 1 & -0.5 day & +0.5 days \\
\hline (Days) & 2 & Current level & +1 days \\
\hline Current level > 1 day & 3 & +0.5 day & +2 days \\
\hline \multirow{3}{*}{$\begin{array}{c}\text { Service frequency } \\
\left(N^{o} \text { of weekly departures }\right)\end{array}$} & 1 & \multirow{3}{*}{ Current level } & 1 weekly departures \\
\hline & 2 & & 2 weekly departures \\
\hline & 3 & & 3 weekly departures \\
\hline
\end{tabular}

Table 5. Attributes and levels for game 1. Efficient design 


\begin{tabular}{|c|c|c|c|}
\hline \multicolumn{2}{|l|}{ Attributes } & Current alternative & $\begin{array}{c}\text { Intermodal alternative } \\
\text { game } 2\end{array}$ \\
\hline $\begin{array}{l}\text { Door-to-door transport } \\
\text { cost } \\
\text { (Euros per shipment) }\end{array}$ & $\begin{array}{l}1 \\
2\end{array}$ & Current level & $\begin{array}{l}+20 \% \\
+10 \% \\
+5 \%\end{array}$ \\
\hline $\begin{array}{c}\text { Door-to-door transit } \\
\text { time } \\
(\text { Days })\end{array}$ & 1 & Current level & $\begin{array}{l}\text { Current level } \\
-0.5 \text { day } \\
-1 \text { day }\end{array}$ \\
\hline $\begin{array}{c}\text { Delay } \\
(\text { Days }) \\
\text { Current level } \leq 0.5 \text { day }\end{array}$ & 1 & $\begin{array}{l}\text { Current level } \\
+0.5 \text { day }\end{array}$ & $\begin{array}{c}-0.5 \text { day } \\
\text { Current level }\end{array}$ \\
\hline $\begin{array}{c}\text { Delay } \\
(\text { Days }) \\
\text { Current level = } 1 \text { day }\end{array}$ & 1 & $\begin{array}{l}\text { Current level } \\
+0.5 \text { day } \\
+1 \text { day }\end{array}$ & $\begin{array}{c}-1 \text { day } \\
-0.5 \text { day } \\
\text { Current level }\end{array}$ \\
\hline $\begin{array}{c}\text { Delay } \\
(\text { Days }) \\
\text { Current level }>1 \text { day }\end{array}$ & $\begin{array}{l}1 \\
2\end{array}$ & $\begin{array}{l}\text {-0.5 day } \\
\text { Current level } \\
+0.5 \text { day }\end{array}$ & $\begin{array}{l}-2 \text { days } \\
-1.5 \text { days } \\
-1 \text { day }\end{array}$ \\
\hline $\begin{array}{c}\text { Service frequency } \\
\left(N^{o} \text { of weekly departures }\right) \\
\text { Current level } \leq 2 \text { dep/week }\end{array}$ & $\begin{array}{l}1 \\
2\end{array}$ & Current level & $\begin{array}{c}2 \text { weekly departures } \\
3 \text { weekly departures } \\
5 \text { weekly departures (Mon to Fri) }\end{array}$ \\
\hline $\begin{array}{c}\text { Service frequency } \\
\left(N^{o} \text { of weekly departures }\right) \\
\text { Current level = } 3 \text { dep/week }\end{array}$ & $\begin{array}{l}1 \\
2 \\
3\end{array}$ & Current level & $\begin{array}{c}3 \text { weekly departures } \\
5 \text { weekly departures (Mon to Fri) } \\
5 \text { weekly departures (Mon to Sun) }\end{array}$ \\
\hline $\begin{array}{c}\text { Service frequency } \\
\left(N^{o} \text { of weekly departures }\right) \\
\text { Current level }>3 \text { dep/week }\end{array}$ & $\begin{array}{l}2 \\
3\end{array}$ & Current level & $\begin{array}{l}5 \text { weekly departures (Mon to Fri) } \\
5 \text { weekly departures (Mon to Sat) } \\
5 \text { weekly departures (Mon to Sun) }\end{array}$ \\
\hline
\end{tabular}

Table 6. Attributes and levels for game 2. Efficient design

The descriptive statistics for the attributes of the current alternative are presented in Table 7. As the variables present a different degree of dispersion, in order to have a better idea of the shape of the distribution, the corresponding quartiles $\left(\mathrm{Q}_{\mathrm{i}}\right)$ are also reported. In this regard, it is worth highlighting the high figure obtained (1.4) for the coefficient of variation (CV) in the cost, which indicates the high dispersion in the observations corresponding to this variable. This is mainly explained by the different nature of the shipments analysed in this study.

\begin{tabular}{|c|c|c|c|c|c|c|c|c|}
\hline Attributes & Mean & Std. Dev. & $\mathbf{C V}$ & $\mathbf{X}_{\min }$ & $\mathbf{X}_{\max }$ & $\mathbf{Q}_{1}$ & $\mathbf{Q}_{\mathbf{2}}$ & $\mathbf{Q}_{\mathbf{3}}$ \\
\hline $\begin{array}{c}\text { Cost } \\
\text { (Euros per shipment) }\end{array}$ & 722.31 & 1009.70 & 1.4 & 20 & 6000 & 100 & 300 & 1150 \\
\hline $\begin{array}{c}\text { Transit time } \\
\text { (Days) }\end{array}$ & 3.64 & 1.78 & 0.49 & 1 & 10 & 2 & 3 & 4 \\
\hline $\begin{array}{c}\text { Service frequency } \\
\text { (Nof weekly departures) }\end{array}$ & 3.24 & 1.53 & 0.47 & 1 & 5 & 2 & 3 & 5 \\
\hline $\begin{array}{c}\text { Delay } \\
\text { (Days) }\end{array}$ & 1.83 & 1.09 & 0.6 & 0.5 & 4.5 & 1 & 1.5 & 2.5 \\
\hline
\end{tabular}

Table 7. Descriptive statistics. Attributes of the current alternative 


\section{MODELLING MODE CHOICE FOR FREIGHT TRANSPORT}

Discrete choice models have been widely used to study individuals' behaviour in the mode choice context. Their theoretical underpinnings are found in the theory of rational choice and in the utility maximisation behavioural rule. Thus, the utility of alternative $j$ to the decision maker $n$ is represented by the random variable $U_{j n}=V_{j n}+\varepsilon_{j n}$; where $V_{j n}$ is the deterministic or observable utility and $\varepsilon_{j q}$ is a random term representing the portion of utility unknown to the analyst. Therefore, under the assumption of utility maximisation, it is only possible to model the choice probability of the different alternatives.

Different assumptions about the distribution of the unobserved portion of utility $\varepsilon_{j n}$ result in different representations of the choice model. Thus, the widely used Multinomial Logit (MNL) and Nested Logit (NL) models are obtained when $\varepsilon_{j n}$ are independent and identically distributed (iid) extreme value and a type of generalised extreme value, respectively (see Train, 2009 and Ortúzar and Willumsen, 2011 to obtain more details about the derivation of the choice probabilities for the different choice models). The Mixed Logit (ML) model solves the main limitations of the MNL and NL models. It allows for random taste variation, unrestricted substitution patterns and even correlation in unobserved factors over time, which is particularly useful when dealing with SP or panel data. It is a very flexible model that can approximate any random utility model with total precision. Under the random coefficient version, the utility of alternative $j$ for an individual $q$ is represented by $U_{j n}=\beta_{n}^{\prime} x_{j n}+\varepsilon_{j n}$, where, $x_{j n}$ is a vector of observed attributes of alternative $j$ for decision-maker $n, \varepsilon_{j n}$ is a set of random variables iid extreme value, and $\beta_{n}$ is a vector of random coefficients. In the error component formulation of the ML model, the utility is represented by $U_{j n}=\alpha^{\prime} x_{j n}+\mu_{n}^{\prime} z_{j n}+\varepsilon_{j n}$, where $x_{j n}$ and $z_{j n}$ are vectors of observed attributes of the alternative $j$ for individual $n, \alpha$ is a vector of fixed coefficients, $\mu_{n}$ is a vector of random terms with zero mean and covariance $W$; and $\varepsilon_{j n}$ are defined as above.

With the purpose of analysing the relative importance of the factors affecting modal choice in the context of freight transport, different discrete choice models were estimated using the data set obtained from the efficient design.

The estimation results are presented in Table 8. The first model MNL3 corresponds to a multinomial Logit model with a linear utility specification similar to that represented in equation (2). All parameter estimates in MNL3 present the expected sign and are significant at the $95 \%$ confidence level. But the multinomial Logit model is very restrictive as error terms are assumed to be independent across observations and all coefficients are forced to be the same for all individuals. Therefore, with this model, all observations are treated as independent and tastes are considered homogeneous in the population. As individuals in our data set provide responses in different choice situations a flexible model of the family of mixed Logit is more appropriate. Thus, in the remaining models we considered a mixed Logit specification including an error component able to account for potential panel correlation $\left(\theta \mu_{i}+\varepsilon_{i n} \quad i=\right.$ road, intermodal $)$. In order to obtain 
homoscedasticity, the common error components of the two alternatives $\mu_{i}$ are assumed to distribute standard Normal for all observations corresponding to the same respondent and were multiplied by a parameter theta to be estimated, as in Hess et al. (2008). In model ML1 all parameters are specified as fixed values and resulted significant with a consistent sign. The parameter theta, in all models resulted significant, indicating the presence of correlation among responses from the same individual.

\begin{tabular}{|c|c|c|c|c|c|c|c|}
\hline \multirow{2}{*}{\multicolumn{2}{|c|}{ Attributes }} & \multicolumn{6}{|c|}{$\begin{array}{c}\text { Estimate } \\
\text { (t-test) }\end{array}$} \\
\hline & & \multirow{2}{*}{$\begin{array}{c}\text { MNL3 } \\
0.349 \\
(3.95)\end{array}$} & \multirow{2}{*}{$\begin{array}{l}\text { ML1 } \\
0.409 \\
(2.78) \\
\end{array}$} & \multirow{2}{*}{\multicolumn{2}{|c|}{$\begin{array}{l}\text { ML2 } \\
0.404 \\
(2.50)\end{array}$}} & \multirow{2}{*}{\multicolumn{2}{|c|}{$\begin{array}{l}\text { ML3 } \\
0.393 \\
(2.34)\end{array}$}} \\
\hline ASC (Current option) & & & & & & & \\
\hline \multirow{2}{*}{$\begin{array}{c}\text { Cost (C) } \\
\text { Euros per shipment }\end{array}$} & \multirow{2}{*}{$\theta_{c}$} & \multirow{2}{*}{$\begin{array}{c}-0.00568 \\
(-8.86)\end{array}$} & \multirow{2}{*}{$\begin{array}{r}-0.00670 \\
(-9.15) \\
\end{array}$} & Mean & $\begin{array}{c}-0.00951 \\
(-7.94)\end{array}$ & Mean & $\begin{array}{l}-0.0151 \\
(-6.02)\end{array}$ \\
\hline & & & & Std err & $\begin{array}{c}0.00503 \\
(3.78)\end{array}$ & Std err & $\begin{array}{c}0.00544 \\
(3.73)\end{array}$ \\
\hline $\begin{array}{c}\text { Transit time }(\mathrm{T}) \\
\text { Days }\end{array}$ & $\theta_{t}$ & $\begin{array}{l}-0.294 \\
(-4.12)\end{array}$ & $\begin{array}{l}-0.328 \\
(-4.28)\end{array}$ & \multicolumn{2}{|r|}{$\begin{array}{l}-0.378 \\
(-4.38)\end{array}$} & \multicolumn{2}{|c|}{$\begin{array}{l}-0.261 \\
(-2.74)\end{array}$} \\
\hline $\begin{array}{c}\text { Delay }(\mathbf{D}) \\
\text { Days }\end{array}$ & $\theta_{d}$ & $\begin{array}{l}0.356 \\
(-5.79)\end{array}$ & $\begin{array}{l}-0.384 \\
(-5.80)\end{array}$ & \multicolumn{2}{|r|}{$\begin{array}{l}-0.474 \\
(-5.90)\end{array}$} & \multicolumn{2}{|c|}{$\begin{array}{l}-0.488 \\
(-5.92)\end{array}$} \\
\hline \multirow{2}{*}{$\begin{array}{c}\text { Frequency (F) } \\
N^{o} \text { of weekly departures }\end{array}$} & \multirow{2}{*}{$\theta_{f}$} & \multirow{2}{*}{$\begin{array}{r}0.0897 \\
(2.4)\end{array}$} & \multirow{2}{*}{$\begin{array}{l}0.122 \\
(2.35)\end{array}$} & Mean & $0.162(2.42)$ & Mean & $\begin{array}{l}0.162 \\
(2.39) \\
\end{array}$ \\
\hline & & & & Std err & $\begin{array}{l}0.503 \\
(3.78) \\
\end{array}$ & Std err & \begin{tabular}{|l|}
0.465 \\
$(3.28)$ \\
\end{tabular} \\
\hline Interaction $\mathbf{C} * \mathbf{C}_{1}$ & & - & - & & $\begin{array}{ll}- \\
-\end{array}$ & & $\begin{array}{l}615 \\
82)\end{array}$ \\
\hline Interaction $\mathbf{T}^{*} \mathbf{T}_{1}$ & & $\begin{array}{l}- \\
-\end{array}$ & - & & $\begin{array}{l}- \\
-\end{array}$ & & $\begin{array}{l}374 \\
81)\end{array}$ \\
\hline Theta & & - & $\begin{array}{l}0.581 \\
(5.95)\end{array}$ & & $\begin{array}{l}0.721 \\
(5.68)\end{array}$ & & $\begin{array}{l}73 \\
92)\end{array}$ \\
\hline$\rho^{2}$ & & 0.147 & 0.176 & & 0.183 & & 97 \\
\hline Adjusted $\rho^{2}$ & & 0.140 & 0.167 & & 0.171 & & 83 \\
\hline$l^{*}(\mathbf{0})$ & & -673.739 & -673.739 & & -673.739 & -67 & .739 \\
\hline$l^{*}(\theta)$ & & -574.523 & -555.386 & & -550.422 & $\overline{-54}$ & .704 \\
\hline Observations & & \begin{tabular}{|l|}
972 \\
\end{tabular} & \begin{tabular}{|l|}
972 \\
\end{tabular} & & 972 & & 22 \\
\hline
\end{tabular}

Table 8. Estimation results. Efficient design data

To analyse random taste heterogeneity different random parameter Logit models were estimated. In order to select the candidate set of random coefficients, the Lagrange Multiplier test, as recommended in Hensher and Green (2003), was applied for different sets of random parameter candidates. Unfortunately none of the tests carried out allowed us to reject the null hypothesis of non-random coefficients. Therefore, we proceeded with the direct specification of random parameters and considering all possible combinations; 
started by assuming all parameters were random and then examined their estimated standard deviations (as suggested in Hensher and Green, 2003). The best model specification (ML2) was that assuming that cost and frequency parameters follow the Normal distribution. As in the former case, all parameters were significant at the $95 \%$ confidence level. Although the mean of the random parameters presented a consistent sign, it is important to point out that, in the case of frequency, the probability of obtaining an inconsistent marginal utility is relatively high (0.37). This result is a consequence of the high dispersion obtained for this random parameter. With regards the latter, one possible explanation could be that, as is the case in the application developed by Feo et al. (2014), while a part of the sample is indeed valuing frequency, the other has a zero value or nearzero value, so in the end the significance of the frequency coefficient for the whole of the population is diminished by the presence of indifferent respondents. Indeed, the results in Figure 2 corroborate this hypothesis, as frequency is the attribute -among those finally included in the SP- displaying the highest heterogeneity: almost $45 \%$ of the sample gave a score of 3 points or less to frequency, while for transport cost, transit time and delays this proportion is $10 \%$ or less. Our next step in future research will be to test this hypothesis considering alternative specifications including attribute $c u t$-offs and latent class models.

To analyse the presence of systematic taste variation, several interactions between socioeconomic variables and service attributes were specified. After testing all possible combinations the best model specification was ML3, where we were only able to find significant interactions between cost and $\mathrm{C} 1$ (which is equal to one if the respondent firm is a producer) and between transit time and $\mathrm{T} 1$ (which is equal to one if the supplier is a producer). This means that the disutility of transport cost is lower when the responsible of the shipment (i.e. the respondent) is a producer than when it is a distributor. This result could be the reflection of the fact that, while the core activity of the former is the production of the good, the core activity of the latter is its distribution, transport being therefore a key determinant of its relative competitiveness. In contrast, the negative perception of transit time is higher when the supplier of the freight is a producer. In that case the result suggests that distributors display larger inventories than producers, which allows them to reduce total delivery times (time from when the order was placed until the shipment is delivered) and therefore to incur in larger transit times (transport time).

As in model ML2, the cost and frequency parameters are normally distributed, and the marginal utility of the frequency is not consistent with a probability of similar magnitude. As ML3 presents the best fit to our data set, this model will be used in model applications in the next section.

Regarding the alternative specific constant, it was specified in the current option and was significant and positive, suggesting the existence of an inertia effect or reluctance to change the mode of transport.

Finally, it is worth pointing out that, in our models, all attributes are treated as continuous variables and are specified in the linear form. With this specification we are limited to 
considering only linear effects with respect to attribute variations. In this regard, Marcucci and Gatta (2014) highlight the importance of testing for the existence of non-linear effects of the different levels of the explanatory variables. These authors treat attributes as discrete variables considering effects coding when defining the corresponding dummies (Hensher et al. 2005), and they find significant differences when comparing WTP measures obtained with linear specifications. As our discrete choice experiment is customised to respondent experience, attribute levels differ across individuals. Therefore, in order to undertake a similar analysis using our data set, a convenient segmentation of each attribute would be required.

\section{MODEL APPLICATION}

\subsection{Willingness to pay measures}

Willingness to pay (WTP) measures represent a key element in the evaluation of transport projects as well as in the design of pricing strategies for transport operators. They provide a quantitative measure of the monetary cost that a user would pay for improving the level of service in the attributes of transport alternatives. WTP measures are obtained from the estimation of discrete choice models as the ratio between the marginal utility of a given attribute and the marginal utility of the transport cost. When random parameters are included in the utility specification, WTP figures are random variables and simulation methods are required to simulate the distribution of the corresponding WTP, which is normally unknown. This is the case when the denominator of the WTP expression distributes Normal, as in our case. In order to obtain plausible values the corresponding distribution of the random parameter is truncated for those values with consistent marginal utility (i.e. with the appropriate sign).

Table 9 presents WTP figures obtained for model ML3. In a first approach, the WTP figures were approximated by the mean of their corresponding simulated distribution. As the mean could be highly affected by the presence of undesirable outliers (note that the denominator of the WTP could have near- 0 values, the median of the distributions was also computed and it is considered a more appropriate measure of the WTP. These two representative figures of the WTP were compared with that obtained by computing the WTP at the estimated mean of the random parameters, observing substantial discrepancies, especially in the case of service frequency. In order to provide the $95 \%$ confidence interval for WTP, the 2.5 and 97.5 percentiles are calculated.

In all cases the median is lower than the mean, giving distributions that are skewed to the right (see Figure 3). In general, WTP figures are higher when the respondent firm is a producer (i.e. when $C_{1}=1$ ). When the supplier is a producer (i.e. when $T_{1}=1$ ) the highest WTP is obtained for saving transit time (ranging from 41,74 to $67,27 € /$ day in the case of the median of the distribution). In contrast, when $\mathrm{T}_{1}=0$, the highest WTP is for reducing delay time. This figure ranges in the case of the median from 32,23 to $51,93 € /$ day. 


\begin{tabular}{|c|c|c|c|c|c|}
\hline \multirow[b]{2}{*}{ Attribute } & \multirow{2}{*}{$\begin{array}{c}\text { Computed at } \\
\text { the mean of the } \\
\text { estimated } \\
\text { parameters }\end{array}$} & \multicolumn{4}{|c|}{ Simulated distribution of the WTP } \\
\hline & & Mean & Median & Percentile 2.5 & Percentile 97.5 \\
\hline \multicolumn{6}{|c|}{$\mathrm{C} 1=0$} \\
\hline Transit time $(\mathrm{T} 1=0)$ & 17.28 & 20.79 & 17.24 & 10.12 & 53.71 \\
\hline Transit time $(\mathrm{T} 1=1)$ & 42.05 & 50.33 & 41.74 & 24.50 & 130.06 \\
\hline Service frequency & 10.73 & 35.20 & 26.07 & 1.28 & 120.86 \\
\hline Delay Time & 32.32 & 38.86 & 32.23 & 18.92 & 100.42 \\
\hline \multicolumn{6}{|c|}{$\mathrm{C} 1=1$} \\
\hline Transit time $(\mathrm{T} 1=0)$ & 29.16 & 38.85 & 27.78 & 13.33 & 143.30 \\
\hline Transit time $(\mathrm{T} 1=1)$ & 70.95 & 94.08 & 67.27 & 32.28 & 347.00 \\
\hline Service frequency & 18.10 & 65.06 & 42.30 & 2.09 & 279.97 \\
\hline Delay Time & 54.53 & 72.64 & 51.94 & 24.93 & 267.94 \\
\hline
\end{tabular}

Table 9. Willingness to pay figures. Model ML3

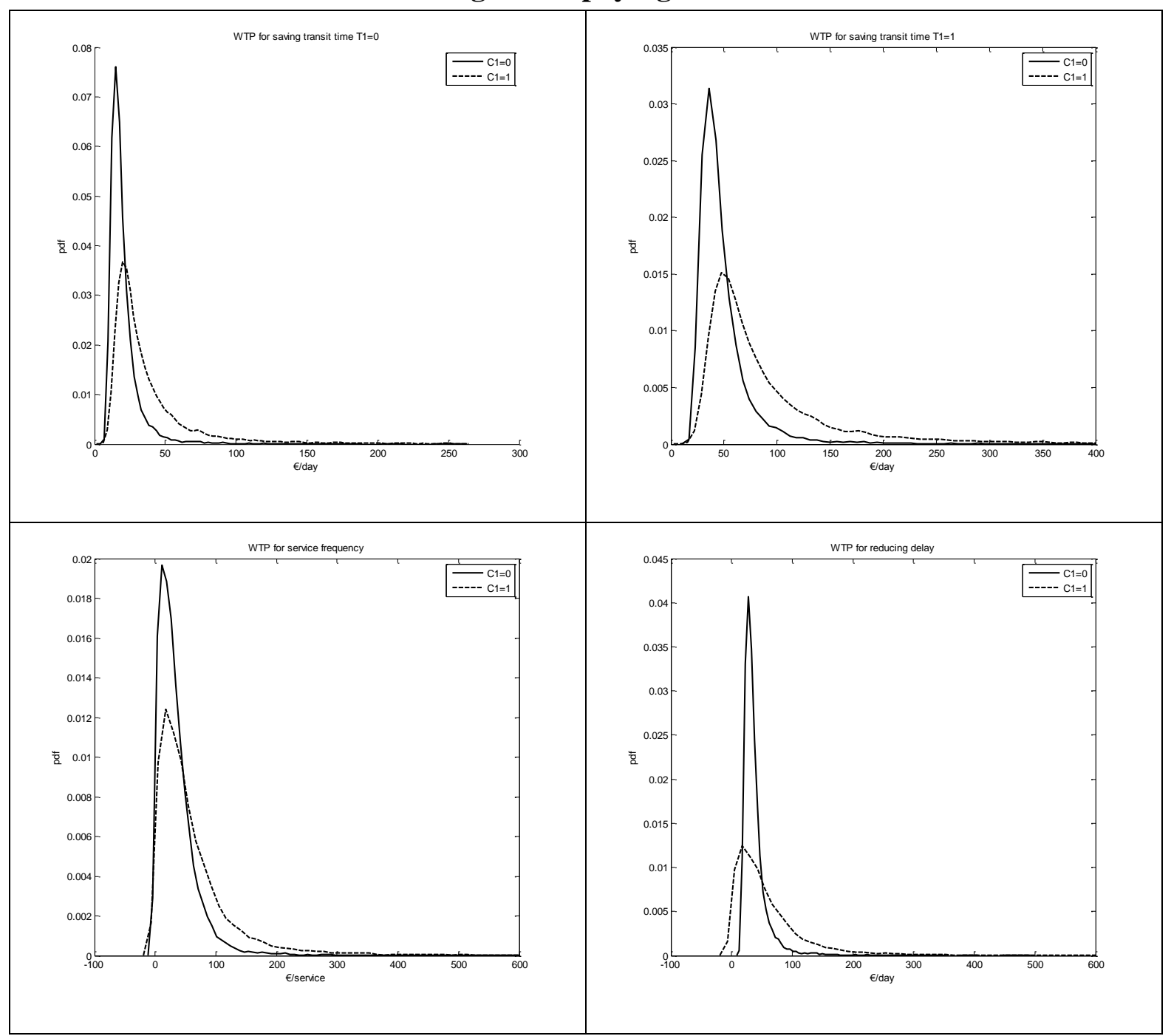

Figure 3. Willingness to pay measures. Probability density function. Model ML3 
In order to test for the validity of our models, WTP figures are compared with those obtained in recent literature. In this sense, a summary of results obtained in previous studies can be consulted in de Jong (2014b) and Rotaris et al. (2012). Regarding the value of transit time our results are in line with those obtained by de Jong (2008) and Fries et al. (2010). Nuzzolo et al. (2013b), using aggregate models obtained VOT figures ranging from 11.71 to $65.89 € / \mathrm{h}$, depending on the mode; and Zamparini and Reggiani (2007) report average values equal to $30.16 \$_{1999} / \mathrm{h}$ for European countries, when comparing several research projects using stated preferences data. Fowkes et al. (2004) reported a value of delay equivalent to 64 pounds per hour, which is fairly consistent with our figures. Less evidence has been found regarding the monetary value of the service frequency, which in many contexts did not result significant. Daniellis and Marcucci (2005), using a non-compensatory choice model incorporating attribute cut-offs, found values of improving service frequency from low to high ranging from 12.5 to 26.9 euros.

\subsection{Elasticities and demand response}

The aggregate elasticities of the choice probabilities for model ML3 were computed using the sample enumeration method (Ben-Akiva and Lerman, 1985; and Ortúzar and Willumsem, 2011) through the expression:

$$
\bar{E}_{x_{j k}}^{P_{i}}=\frac{\sum_{q} E_{x_{j k q}}^{P_{i q}} P_{i q}}{\sum_{q} P_{i q}}
$$

where $E_{x_{j k q}}^{P_{i q}}$ represents the elasticity of the probability of alternative $i$ for individual $q\left(P_{i q}\right)$ with respect to the attribute $x_{j k q}$. To obtain elasticities at the individual level, it is common practice to compute the arc elasticities as:

$$
E_{x_{j k q}}^{P_{i q}}=\frac{P_{i q}^{f}-P_{i q}^{0}}{P_{i q}^{0}} \times 100
$$

where $P_{i q}^{f}$ represents the choice probability of alternative $i$ for individual $q$ after a marginal change ( $1 \%$ increase) in attribute $x_{j k q}$ with respect to the base situation, and $P_{i q}^{0}$ represents the choice probability in the base situation. Direct elasticities are obtained for $j=i$ in expressions (3) and (4), and cross elasticities when $j \neq i$.

As our model includes random parameters, the choice probabilities are random variables and some simulation work is required to compute the simulated choice probabilities for every individual in the sample, before and after change. For this purpose, the Matlab software was used to generate 10,000 random draws of the distribution of the random parameters and error components. The simulated choice probabilities are obtained by averaging the choice probabilities evaluated at the different draws. 
Table 10 presents direct and cross elasticities of the choice probability of road transport and the intermodal alternative for model ML3. In the right hand columns we compute the elasticity values using the simulating procedure described above. These figures are compared with those obtained by the naive approach (left hand column) where the elasticities are computed evaluating the choice probabilities at the mean of the distribution of the estimated random parameters. Although the relative interpretation of the elasticity values for both methods is similar, the simulation method provides less elastic figures in most of the attributes.

In the case of direct elasticities, an increase in cost, transit and delay times causes a decrease in the probability of choosing the corresponding mode of transport. In contrast, an increase in service frequency increases the probability of choosing this alternative, as expected. In general, the probability of the intermodal alternative exhibits more elastic figures with respect to cost, transit time and service frequency when simulated probabilities are used. Regarding their magnitude, the highest sensitivity of demand is found for policies involving changes in transport cost. According to the figures presented in Table 10 for the method of simulated probabilities, a $1 \%$ increase in transport cost would reduce the probability of choosing road transport in $1.53 \%$; and the probability of choosing the intermodal option in $1.79 \%$. Changes in the rest of the attributes affect, to a lesser extent, the probability of choosing the corresponding mode, although it is important to note that demand response is higher when changes in transit time are produced. It is also important to highlight the low response of the probability of road transport $(0.08 \%)$ with respect to changes in service frequency, in comparison with the intermodal alternative $(0.25 \%)$, which might be a consequence of the high level of service currently offered by road transport in terms of frequency. Indeed, during the first phase of the fieldwork interviewees were asked to rate the level of satisfaction with the levels of service offered by the current road transport alternative. As can be seen in Figure 4, frequency is, after schedules, the attribute that concentrates the higher proportion of "very satisfied" companies. Again figures in brackets below the name of the attribute represent the average score obtained by this attribute regarding the level of satisfaction.

As expected, cross elasticities also present consistent figures, regarding the direction of change, when marginal increases in the attributes of competing mode are produced. Unlike direct elasticities, the probability of the intermodal alternative is more elastic than the road with respect to changes in cost, transit time and delay of the competing mode. As in the former case, the higher sensitivity of demand is found for those policies affecting the transportation costs of the competing modes. This result suggests that transport operators could compete via prices as the cross cost elasticities are higher than the cross transit time, delay and service frequency elasticities.

Elasticity figures represent one of the most important tools for analysing demand response and modal competition. In this sense, our analysis of elasticities would allow transport planners to evaluate the demand response to different policies consistent with the 
directions of the European transport policy; i.e. favouring the deviation of traffic from roads (the current option) to alternative modes (rail and short sea shipping). As can be inferred from our results, the actions with the greatest impact on the share of intermodal alternatives are those that affect the cost of transportation. Therefore, in terms of modal shift, both road pricing schemes (like that introduced in 2005 in Germany or the Eurovignette) as bonus initiatives to alternative modes, such as the Ecobono or the subsidy given by the Spanish Government, undoubtedly will have a positive impact on the modal pattern. However, it is worth highlighting the fact that an increase in the cost of road transport has a slightly greater effect on the probability of choosing intermodal transport than that caused by improving the cost of intermodal alternatives itself. This result is in line with that obtained in previous research (Feo et al., 2011; de Jong et al., 2004). On the contrary, in terms of frequency, the probability of the intermodal mode being chosen depends on its own performance, while road transport is more elastic to changes in the levels offered by intermodal modes. Here again, the result obtained suggests the high level of service offered by the road transport alternative in terms of frequency compared to that of intermodal modes. Improving frequency levels appears as a key determinant of the capacity of intermodal modes for attracting significant cargo from pure road transport.

\begin{tabular}{|c|c|c|c|c|}
\hline \multicolumn{5}{|c|}{ Direct elasticities } \\
\hline \multirow{2}{*}{$\begin{array}{l}\text { Attributes of the } \\
\text { own mode }\end{array}$} & \multicolumn{2}{|c|}{ Elasticity of the probability of road } & \multicolumn{2}{|c|}{$\begin{array}{l}\text { Elasticity of the probability of the } \\
\text { intermodal alternative }\end{array}$} \\
\hline & $\begin{array}{l}\text { Using the mean of } \\
\text { est. parameters }\end{array}$ & $\begin{array}{l}\text { Using simulated } \\
\text { probabilities }\end{array}$ & $\begin{array}{l}\text { Using the mean of } \\
\text { est. parameters }\end{array}$ & $\begin{array}{c}\text { Using simulated } \\
\text { probabilities }\end{array}$ \\
\hline Cost & -1.79 & -1.53 & -2.49 & -1.79 \\
\hline Transit time & -0.43 & -0.37 & -0.72 & -0.55 \\
\hline Service frequency & 0.15 & 0.08 & 0.25 & 0.25 \\
\hline Delay time & -0.27 & -0.27 & -0.35 & -0.20 \\
\hline \multicolumn{5}{|c|}{ Cross elasticities } \\
\hline \multirow[t]{2}{*}{$\begin{array}{l}\text { Attributes of the } \\
\text { competing mode }\end{array}$} & \multicolumn{2}{|c|}{$\begin{array}{l}\text { Elasticity of the } \\
\text { probability of road }\end{array}$} & \multicolumn{2}{|c|}{$\begin{array}{c}\text { Elasticity of the } \\
\text { probability of the intermodal } \\
\text { alternative }\end{array}$} \\
\hline & $\begin{array}{l}\text { Using the mean } \\
\text { of est. parameters }\end{array}$ & $\begin{array}{l}\text { Using simulated } \\
\text { probabilities }\end{array}$ & $\begin{array}{l}\text { Using the mean } \\
\text { of est. parameters }\end{array}$ & $\begin{array}{c}\text { Using simulated } \\
\text { probabilities }\end{array}$ \\
\hline Cost & 1.70 & 1.31 & 2.61 & 2.09 \\
\hline Transit time & 0.50 & 0.40 & 0.63 & 0.51 \\
\hline Service frequency & -0.17 & -0.19 & -0.22 & -0.11 \\
\hline Delay time & 0.24 & 0.14 & 0.40 & 0.36 \\
\hline
\end{tabular}

Table 10. Elasticities. Model ML3 


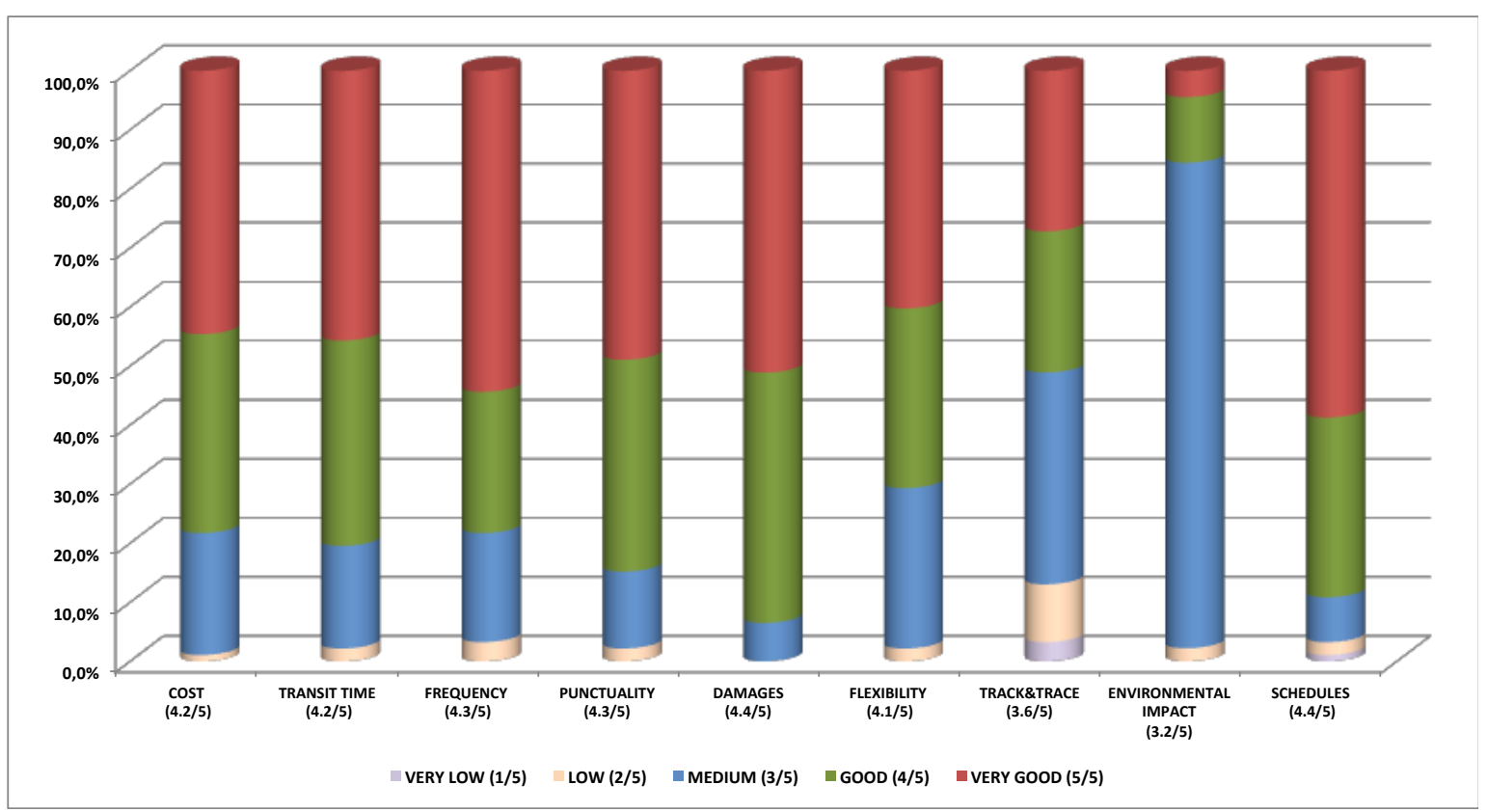

Figure 4. Level of satisfaction with levels of service offered by the current road transport alternative

Comparing our results with the existing literature, our model predicts direct cost elasticity figures for the probability of road transport that are slightly higher than those obtained in other studies (de Jong, 2014b; Beuthe et al., 2001; and Nuzzolo et al., 2013b). In one of the most complete reports focused on road transport elasticities de Jong et al. (2010), after analysing more than 70 published papers, found that for European long distance road freight transport the tonne-kilometres price elasticity varies between -0.2 to -1.3 . In this regard, it is important to point out that the methodology applied to estimate demand differs substantially among the different works. In contrast, figures obtained for the cross cost elasticity of the probability of road transport are similar to those presented in the de Jong study $(2014 b)$ when the alternative to road is rail transport.

\section{CONCLUSIONS}

In this paper we applied discrete choice models to analyse the main factors that determine modal choice in freight transport with the aim of shedding some light on the debate about rebalancing the modal pattern for freight flows between Spain and Europe.

Models are based on the estimation of the utility of the alternatives using an SP data set that has been obtained applying advanced techniques in the construction of experimental data. Thus an efficient design based on the minimisation of the D-error was used to create our data set. The special care taken during the construction of the experiment allowed us to concentrate on one fundamental aspect of experimental data: the reduction of the hypothetical bias. In this regard, good quality information for parameter priors was obtained from a preliminary model estimated with orthogonal data; and a specific efficient design, tailored for every respondent, was created in order to improve experiment outcomes, which is not usual practice due to the high costs of implementation. 
Results obtained confirm the convenience of policies undertaken at both European and national level in favour of charging for infrastructure use and the internalisation of external costs related to transport. Indeed, according to estimated models, the actions with the greatest impact on the deviation of traffic to alternative modes are those that affect the cost of transportation.

As for the theoretical implications, much of the discussion throughout the paper has been focused on the obtaining of good-quality datasets, which is especially relevant when dealing with experimental data. Moreover, the difficulties associated with data collection in the freight transport sector further reinforce this argument. In this regard, dedicated efforts to improve the way in which data are collected are paramount.

One of the strengths of this research is the richness of the information provided by our data set. This will allow us to extend the scope for future research which can be extended in the following directions: i) to incorporate the elements of the Prospect Theory by specifying a reference dependent utility, capable of accounting for the differentiated effect of gains and losses with respect to a reference value; ii) to analyse the existence of non-compensatory behaviour by considering attribute cut-offs; and iii) to incorporate latent elements in the decision making process by specifying hybrid choice models. In addition, the comparison of results arising from this future research will allow us to draw interesting conclusions, in both the theoretical and empirical arena, which will contribute positively to the body of knowledge of freight transport demand analysis.

\section{ACKNOWLEDGEMENTS}

The authors acknowledge the financial support provided by the Project "Modelización de previsiones de tráfico de mercancías y posibilidades de transporte intermodal con Europa (PREVITRANS)". Expediente P4/08. Ministerio de Fomento. Convocatoria de ayudas del Programa Nacional de Cooperación público-privada, Subprograma de proyectos relativos a transporte e infraestructuras, en el marco del Plan Nacional de I+D+i, 2008-2011.

\section{REFERENCES}

Arunotayanun K. and Polak, J. W. (2011). Taste heterogeneity and market segmentation in freight shippers' mode choice behaviour. Transportation Research Part E 47, 138-148.

Ben-Akiva, M. and Lerman, S.R. (1985). Discrete Choice Analysis: Theory and Application to Travel Demand. The MIT Press, Cambridge. Mass.

Ben-Akiva, M., Bolduc, D. and Park, J.Q. (2008). Discrete choice analysis of shippers' preferences. In Ben-Akiva, M., Meersman, H. and Van de Voorde, E. (eds). Recent Developments in Transport Modelling. Lessons for the Freight Sector, Emerald Group Publishing Limited, Bingley, U.K., 135-155.

Ben-Akiva, M., Meersman, H., and van de Voorde, E. (2013). Freight Transport Modelling. Emerald Group Publishing Limited, Bingley, U.K. 
Bergantino, A.S., Bierlaire, M., Catalano, M., Migliore, M. and Amoroso, S. (2013). Taste heterogeneity and latent preferences in the choice behaviour of freight transport operators. Transport Policy 30, 77-91.

Bergantino, A. S. and Bolis, S. (2008). Monetary value of transport service attributes: land versus maritime ro-ro transport. An application using adaptive stated preferences. Maritime Policy and Management 35(2), 159-174.

Beuthe, M. and Bouffioux, C. (2008). Analysing attributes of freight transport from stated orders of preference experiment. Journal of Transport Economics and Policy 42(1), 105128.

Beuthe, M., Jourquin, B., Geerts, J.F. and Ha, C.K.N. (2001). Freight transportation demand elasticities: a geographic multimodal transportation network analysis. Transportation Research Part E 37 (4), 253-266.

Bierlaire, M. (2003). BIOGEME. A free package for the estimation of discrete choice models. Proceedings of the 3rd Swiss Transportation Research Conference, Ascona, Switzerland.

Bierlaire, M. (2008). An introduction to BIOGEME Version 1.7. Available in http://transpor2.epfl.ch/biogeme/doc/tutorialv17.pdf

Bliemer, M.C.J. and Rose, J.M. (2005). Efficiency and Sample Size Requirements for Stated Choice Studies. Report ITLS-WP-05-08, Institute of Transport and Logistics Studies, University of Sydney.

Brooks, M. R. and Trifts, V. (2008). Short sea shipping in North America: understanding the requirements of Atlantic Canadian shippers. Maritime Policy and Management 35(2), $145-158$.

ChoiceMetrics (2009), Ngene 1.0. User manual \& reference guide. The Cutting Edge in Experimental Design. www.choice-metrics.com

Chow, J.Y.J., Yang, C.H.Y. and Regan, A.C. (2010). State-of-the art of freight forecast modelling: lessons learned and the road ahead. Transportation 37(6), 1011-1030.

Cullinane, K. and Toy, N. (2000). Identifying influential attributes in freight route/mode choice decisions: a content analysis. Transportation Research Part E 36(1), 41-53.

Danielis, R. and Marcucci, E. (2005). Attribute cut-offs in freight service selection. In Transportation Research Part E: Logistics and Transportation Review 43(5), 506-515.

de Jong, G. (2008). Value of freight travel-time savings, revised and extended chapter. In Hensher, D.A. and Button, K.J. (eds). Handbook of Transport Modelling, Elsevier, Oxford, U.K., 553-563

de Jong, G. (2014a). Mode Choice Models. In Tavasszy, L. and de Jong, G. (eds). Modelling Freight Transport, Elsevier, London, U.K., 117-141. 
de Jong, G. (2014b). Freight Service Valuation and Elasticities. In Tavasszy, L. and de Jong, G. (eds). Modelling Freight Transport, Elsevier, London, U.K., 201-227.

de Jong, G. and Ben-Akiva, M. (2007). A micro-simulation model of shipment size and transport chain choice. Transportation Research Part B: Methodological 41 (9), 950-965.

de Jong, G., Gunn, H., Ben-Akiva, M., (2004). A meta-model for passenger and freight transport in Europe. Transport Policy 11, 329-344.

de Jong, G., Schroten, A., Van Essen, H., Otten, M. and Bucci, P. (2010). Price sensitivity of European road freight transport - towards a better understanding of existing results. A report for Transport \& Environment. 9012-1, C Delft, The Netherlands.

de Jong, G., Vierth, I., Tavasszy, L. and Ben-Akiva, M. (2012). Recent developments in national and international freight transport models within Europe. Transportation 40 (2), 347-371.

Domencich, T.A. and McFadden, D. (1975). Urban Travel Demand. A Behavioral Analysis. North Holland, Amsterdam.

European Commission (2001). White Paper: European Transport Policy for 2010: Time to Decide. Available at

"http://ec.europa.eu/transport/themes/strategies/doc/2001_white_paper/lb_com_2001_0370 _en.pdf"

Feo-Valero, M., Espino-Espino, R. and García-Menéndez, L. (2011). A stated preference analysis of Spanish freight forwarders modal choice on the South-West Europe Motorway of the Sea. Transport Policy 18, 60-67.

Feo-Valero, M., García-Menéndez, L. and del Saz-Salazar, S. (2014). Rail freight transport and demand requirements: an analysis of attribute cut-offs through a stated preference experiment. Transportation, (DOI) 10.1007/s11116-014-9566-x.

Feo-Valero, M., García-Menéndez, L. and Garrido-Hidalgo, R. (2011). Valuing Freight Transport Time using Transport Demand Modelling: A Bibliographical Review. Transport Reviews 31(5), 625-651.

Fowkes, A.S., Firmin, P.E., Tweddle, G., Whiteing, A.E. (2004). How Highly Does the Freight Transport Industry Value Journey Time Reliability - and for What Reasons? International Journal of Logistics: Research and Applications 7, 33-44.

Fries, N., de Jong, G., Patterson, Z. and Weidmann, U. (2010). Shipper willingness to pay to increase environmental performance in freight transportation. Transportation Research Record 2168, 33-42.

Hensher, D.A. and Green, W.H. (2003). The Mixed Logit model: The state of practice. Transportation 30 (2), 133-176.

Hensher, D.A., Rose, J.M, and Greene, W.H. (2005). Applied choice analysis: a primer. Cambridge University Press, Cambridge. 
Hess, S., Rose, J. M. and Hensher, D.A. (2008). Asymmetric preference formation in willingness to pay estimates in discrete choice models. Transportation Research Part E 44, 847-863.

Kocur, G., Adler, T., Hyman, W. and Aunet, B. (1982). Guide to forecasting travel demand with direct utility assessment. Report $\mathrm{n}^{\circ}$ UMTA-NH-11-0001-82, Urban Mass Transportation Administration, US Department of Transportation, Washington DC.

Kurri, J., Sirkia, A. and Mikola, J. (2000). Value of time in freight transport in Finland. Transportation Research Record 1725, 26-30.

Manski, C. (1977). The structure of random utility models. Theory and Decision 8, 229254.

Marcucci, E. and Gatta, V. (2014), Behavioural modelling of urban freight transport. Testing non-linear policy effects for retailers. In Gonzalez-Feliu, J. et al. (eds). Sustainable Urban Logistics: Concepts, Methods and Information Systems, Springer-Verlag, Berlin, 227-243.

Marcucci, E. and Scaccia, L. (2004). Mode choice models with attribute cutoffs analysis: the case of freight transport in the Marche region. European Transport 25-26, 21-32.

Masiero, L. and Hensher, D. (2012). Freight transport distance and weight as utility conditioning effects on a stated choice experiment. Journal of Choice Modelling 5(1), 6476.

McFadden, D. (1974). The measurement of urban travel demand. Journal of Publics Economics 3, 303-328.

Modenese-Vieira, L.F. (1992). The value of service in freight transportation. Ph.D. thesis, MIT, Boston.

Nuzzolo, A., Coppola, P. and Comi, A. (2013a). Freight transport modeling: review and future challenges. International Journal of Transport Economics XL (2), 151-181.

Nuzzolo, A., Crisalli, U. and Comi, A. (2013b). An aggregate transport demand model for import and export flow simulation. Transport, DOI:10.3846/16484142.2013.820215, Francis \& Taylor.

Nuzzolo, A. and Russo, F. (1997). Modal split at international level: a system of models for Italian-based freight. Proceedings of European Transport Conference, Brunel, UK.

Ortúzar, J. de D. and Willumsen, L.G. (2011). Modelling Transport. 4th edition, John Wiley \& Sons, Chichester.

Polak, J. and Arunotayanun K. (2009). Accommodating supply chain structure in models of freight mode choice. Proceedings of the 12th International Conference of Travel Behavior Research, Jaipur, India. 
Rich, J., Holmblad, P.M. and Hansen, C.O. (2009). A weighted logit freight mode-choice model. Transportation Research Part E 45, 1006-1019.

Rose, J.M. and Bliemer, M.C.J. (2009). Constructing efficient stated choice experimental designs. Transport Reviews: A Transnational Transdisciplinary Journal 29(5), 587-617.

Rose, J.M., Bliemer, M.C.J., Hensher, D. A. and Collins, A.C. (2008). Designing efficient stated choice experiments involving respondent based reference alternatives. Transportation Research Part B 42 (4), 395-406.

Rotaris, L., Danielis, R., Sarman, I. and Marcucci, E. (2012). Testing for nonlinearity in the choice of a freight transport service. In European Transport 50, 1-22.

Shinghal, N. and Fowkes, T. (2002). Freight mode choice and adaptive stated preferences. Transportation Research Part E 38, 367-378

Taniguchi, E. and Ando, N. (2005). An experimental analysis on probabilistic vehicle routing and scheduling with ITS. Journal of the Eastern Asia Society for Transportation Studies (6), 3052-3061.

Tavasszy, L. and de Jong, G. (2014). Modelling Freight Transport, Elsevier, London, U.K. Train, K. (2009). Discrete Choice Methods with Simulation, 2nd edition, Cambridge University Press, Cambridge.

Winston, C. (1983). The demand for freight transportation: models and applications. Transportation Research 17A, 419-427.

Zamparini, L. and Reggiani, A. (2007). The value of travel time in passenger and freight transport: An overview. Invan Geenhuizen, M., Reggiani, A., Rietveld, P. (eds). Policy analysis of transport networks. Ashgate Publishing, Aldershot.

\footnotetext{
${ }^{1}$ Flexibility was defined as the capacity of the transport provider to adapt to unexpected changes in the requirements of the demand, for example a last-minute change in the size of the shipment, or on the final destination.

2 Transport providers' schedules meeting the needs of the company.

${ }^{3}$ Intermodal transport chains where origin/destination haulage is carried out by alternative modes to road (basically rail in the case of the sea-intermodal transport option) were discarded because, given the current configuration of the Spanish rail sector, resulting door-to-door transit times would be very high and therefore the proposed scenario would be perceived as unrealistic.

${ }^{4}$ It was a sequential orthogonal design, in which orthogonality only holds within each alternative.

${ }^{5}$ A complete revision on the formulation of different choice models can be found in Train (2009). In the next section we present a brief description of the formulation of the different choice models.

${ }^{6}$ As pointed out by Taniguchi and Ando (2005) early arrivals -arrivals before the customers time window opens- also imply logistics costs. However for reasons of simplicity in our research we have focused only on the analysis of delays.
} 
${ }^{7}$ Personal communication (John Rose, May 2013). 